\title{
ОРГАНІЗАЦІЙНО-ВИХОВНА ПРАКТИКА В ДИТЯЧИИХ ТАБОРАХ ОЗДОРОВЛЕННЯ ТА ВІДПОЧИНКУ
}

\author{
Цапко А. М. \\ кандидат педагогічних наук, доцент кафедри освітології та інноваційної \\ педагогіки, Харківський національний педагогічний університет \\ імені Г. С. Сковороди, м. Харків, Україна
}

\section{Кабанська Г. А.}

завідувач відділом практик, Харківський національний педагогічний університет імені Г. С. Сковороди, м. Харків, Україна

У статті розкрито проиееуру організаиії літньої практики майбутніх учителів у дитячих таборах. Заначено, щуо вихователь організовує творче колективне життя дітей, пробуджує в них ініціативу, самостійність.

Ключові слова: організаційно-виховна практика, дитячий колектив, вожатий, дозвілля дітей, професійна діяльність, дитячий табір оздоровлення та відпочинку.

The article reveals the procedure for organizing summer internships for future teachers in children's camps. It is noted that the educator organizes the creative collective life of children, awakens in them initiative, independence.

Key words: organizational and educational practice, children's collective, counselor, children's leisure, professional activity, children's camp of improvement and rest.

У системі професійної підготовки учительських кадрів важлива роль належить літній організаційно-виховній практиці здобувачів вищої освіти у ДЗОВ. Така практика є складовою частиною освітнього процесу в ЗВО. Виховна робота в дитячому оздоровчому таборі включає розумне поєднання відпочинку, праці, спорту з пізнавальною, естетичною, оздоровчою діяльністю. Контингент дітей у таборі різний за рівнем вихованості, загальним розвитком, інтересами, ідеалами, світоглядом. Здобувачі першого (бакалаврського) рівня вищої освіти 3 року навчання проходять обов'язкову організаційно-виховну практику на посадах організаторів дитячого дозвілля, вожатих, вихователів, спортивних інструкторів (плавруків). 
Метою організаційно-виховної практики є розширення, поглиблення та закріплення професійно-педагогічних знань студентів, набуття ними досвіду самостійної організації життя та діяльності тимчасового дитячого колективу під час літнього відпочинку; формування вмінь та навичок поєднувати колективні, групові та індивідуальні форми роботи; удосконалення організаційних, комунікативних, творчих умінь майбутнього вчителя; підготовка до виконання виховних функцій.

Основними завданнями практики є: ознайомлення з умовами побуту, правилами внутрішнього розпорядку, традиціями оздоровчого закладу, що виступає базою практики; виявлення специфіки виховної діяльності в період канікул, літнього відпочинку; поглиблення, закріплення й застосування знань із загальної педагогіки, основ педагогічної майстерності, соціальної педагогіки, психології; формування у студентів професійних якостей, власного стилю професійної діяльності; вивчення специфіки проявів вікових та індивідуальних особливостей дітей, стану їхнього здоров'я, умов життя та виховання; формування й розвиток у майбутніх педагогів навичок педагогічного спілкування 3 дітьми; вивчення специфіки планування виховної роботи в тимчасовому дитячому колективі; організація самообслуговування дітей, колективно-творчої діяльності за всіма напрямами виховання (розумового, морального, естетичного, трудового, фізичного, екологічного тощо) $[1 ; 2]$.

Підготовка студентів до роботи у ДЗОВ відбувається на зборі-семінарі. Під час проходження навчання здобувачі отримують теоретичні і практичні навички організації виховної роботи у дитячих закладах оздоровлення та відпочинку. Така підготовка відбувається за двома модулями:

\section{Модуль 1. Підготовка студентів до роботи у ДЗОВ:}

1.1. Місце організаційно-виховної практики в системі професійної підготовки майбутніх учителів

1.2. Педагогічні можливості ДЗОВ. Логіка табірної зміни. Планування виховної роботи в таборі, загоні.

1.3. Організація праці вожатого. Педагогічний стиль вожатого. Педагогічна етика в умовах ДЗОВ 
1.4. Охорона життя та здоров’я дітей у ДЗОВ

1.5. Особливості створення тимчасового дитячого колективу. Самоврядування та співуправління у таборі дітей

1.6. Психологічні основи роботи вожатого з різними категоріями

1.7. Психологія ефективного спілкування в умовах ДЗОВ

1.8. Розвиток творчих здібностей та інтересів дітей у ДЗОВ

1.9. Організація та проведення масових заходів у ДЗОВ

1.10. Ігротехніка. Банк ігор та ігрових форм для ДЗОВ

1.11. Методика організації та проведення туристичної діяльності

Модуль 2. Педагогічна діяльність студентів у ДЗОВ:

2.1. Ознайомлення із завданнями та змістом практики

2.2. Знайомство з базою практики

2.3. Знайомство з вихованцями та їхніми батьками

2.4. Вивчення специфіки прояву вікових та індивідуальних особливостей дітей

2.5. Робота по формуванню тимчасового дитячого колективу

2.6. Організація трудової діяльності дітей

2.7. Організація ігрової діяльності дітей

2.8. Організація художньо-творчої діяльності дітей у загоні й гурткової діяльності у таборі

2.9. Організація оздоровчо-спортивної діяльності дітей

2.10. Проведення індивідуальної виховної роботи з дітьми, які мають проблеми у сфері міжособистісного спілкування в колективі

2.11. Вивчення соціально-психологічного клімату педагогічного колективу

2.12. Підбиття підсумків організації діяльності тимчасового дитячого колективу

2.13. Узагальнення отриманих на практиці результатів

2.14. Захист результатів практики

Після успішного проходження навчання обсягом 18 годин на зборі-семінарі і виконання завдань його програми студенти отримують сертифікат [1].

Здобувачі першого (бакалаврського) рівня вищої освіти у 2020-2021 навчальному році після проходження практики мали надати звіт з організаційно-виховної практики у ДЗОВ у вигляді портфоліо: 
Розділ II. Особистісні та соціальні детермінанти духовно-інтелектуального виховання і навчання в системі неперервної освіти

\begin{tabular}{|c|c|c|}
\hline Сертифікат & \multicolumn{2}{|l|}{30 балів } \\
\hline \multirow{6}{*}{$\begin{array}{l}\text { Характеристика студента- } \\
\text { практиканта. }\end{array}$} & \multicolumn{2}{|l|}{20 балів } \\
\hline & $\begin{array}{c}\text { Бали, } \\
\text { отримані в } \\
\text { характеристиці }\end{array}$ & $\begin{array}{c}\text { Бали, що } \\
\text { додаються до } \\
\text { загальної оцінки }\end{array}$ \\
\hline & $0-59$ & 5 \\
\hline & $60-73$ & 10 \\
\hline & $74-89$ & 15 \\
\hline & $90-100$ & 20 \\
\hline Звіт здобувача вищої освіти & \multicolumn{2}{|l|}{5 балів } \\
\hline $\begin{array}{l}\text { Паспорт загону (назва, емблема, } \\
\text { девіз, речівка, пісня) (фото } \\
\text { підтвердження) }\end{array}$ & \multicolumn{2}{|l|}{8 балів } \\
\hline $\begin{array}{l}\text { План роботи загону на зміну (план } \\
\text { сітка). }\end{array}$ & \multicolumn{2}{|l|}{2 бали } \\
\hline $\begin{array}{l}\text { Методичні розробки двох виховних } \\
\text { заходів, розроблених та проведених } \\
\text { здобувачем вищої освіти для загону } \\
\text { (з фото та відео підтвердженням). }\end{array}$ & \multicolumn{2}{|l|}{10 балів } \\
\hline $\begin{array}{l}\text { Розробка } 5 \text { ігор: гра на знайомство, } \\
\text { інтелектуальна гра, рухлива гра, } \\
\text { настільна гра, рольова гра. }\end{array}$ & \multicolumn{2}{|l|}{10 балів } \\
\hline $\begin{array}{l}\text { Методика підготовки одного } \\
\text { загальнотабірного заходу (відповідно } \\
\text { до плану-сітки табору) (з фото та } \\
\text { відео підтвердженням). }\end{array}$ & \multicolumn{2}{|l|}{10 балів } \\
\hline $\begin{array}{l}\text { Презентація портфоліо на } \\
\text { підсумковій конференції (2 хвилини) }\end{array}$ & \multicolumn{2}{|l|}{5 балів } \\
\hline
\end{tabular}

Отже, бути педагогом-вихователем, вожатим у дитячому оздоровчому таборі - це бути поруч і трохи попереду, що означає вміти організувати творче колективне життя дітей, пробудити в них ініціативу, 
самостійність. Це отримати досвід творчого самовираження в процесі розробки атрибутики загону та професійних навичок розв'язання педагогічних ситуацій.

\section{Список використаних джерел:}

1. Організаційно-виховна практика студентів у дитячих закладах оздоровлення та відпочинку: методичні рекомендації студентам-практикантам / уклад. Балацинова А. Д.; заг. ред. Золотухіна С. Т. Харків : ХНПУ імені Г. С. Сковороди, 2014. 50 с.

2. Войчун О. В. «Методика роботи в дитячих оздоровчих закладах» : методичні рекомендації для студентів III курсу факультету фізичної культури та спорту. Миколаїв : МНУ, 2019.103 с. 